\title{
The Land Registration Act 2002
}

Received: 7 July 2003

\section{Geoffrey Silman}

has practised as a property solicitor for 30 years, specialising in commercial landlord and tenant law with an emphasis on advising retailers on their acquisitions, disposals and management issues. He was co-founder of the firm Nathan, Silman, which had a reputation as a niche retail practice, and for the last two years has been a consultant at Finers Stephens Innocent following the merger of the two firms. He has written extensively for Estates Gazette, Retail Week, Property Law Journal and Property Week and has spoken at a workshop at the BCSC annual conference. He has also spoken at Henry Stewart seminars.

\section{Abstract}

The development of land registration, coupled with the availability to the public of as much information as possible about all property interests, has led to the first major piece of legislation in this field for nearly 80 years. It is also a prelude to e-conveyancing.

13 October 2003 was D-Day and all those involved in property need to be aware. Many of the provisions are procedural and primarily of concern to the professional, but others affect the client directly.

This paper seeks to summarise the most important changes, the background to them and the possible implications.

\section{Keywords:}

more registerable interests, open to view, e-conveyancing, abolition of deeds, simplification, new Rules

\section{A WHOLE NEW WORLD}

There are dates etched in one's mind, and it is no exaggeration to say that almost everyone can recollect where they were on the occasion of momentous events. For those old enough there was Kennedy's assassination (interrupting Latin homework and Emergency Ward 10) and, much more recently, September 11th (in Majorca to see them play Arsenal).

13 October 2003 might well come into that category for a property lawyer. On that date the Land Registration Act 2002 ('the Act') and the accompanying Rules ('the Rules') which provide the 'nuts and bolts' of registered conveyancing came into force. The Rules are made by the Rule Committee appointed pursuant to s. 127 of the Act, which also determines who will be the members.

Geoffrey Silman

Finers Stephens Innocent 179 Great Portland Street London $\mathrm{W}_{1} \mathrm{~W} 5 \mathrm{LS}$, UK Tel: +44 (o) 2073447659 Fax: +44 (o)20 73445605 E-mail: gsilman@fsilaw.co.uk The Act represents the first complete overhaul to the law in this area since 1925, and by s. 122(1) repeals the first statute to provide for the registration of title in England, the Land Registry Act 1862.

It is also stated by the Chief Land Registrar to be the largest single item of law reform undertaken by the Law Commission since 
it was set up in 1965. The Act is a prelude to e-conveyancing and contains provisions to allow for it when appropriate rules are put in place. There are many issues (including electronic signatures and authentication) which have to be looked into and consulted upon, and no date has yet been set for this technological revolution to come into force, but this is the precursor - the mini-revolution. The Act also contains a range of other provisions that increase the extent to which the register gives a complete and accurate reflection of the state of the title.

In the bad old days before land was registered and even while the spread of registration gradually took over the country (compulsory registration on sale for the whole of England and Wales only applied from 1 December 1990), solicitors would pore over wonderful old handwritten deeds (all the handwriting appears the same, and it seems that there was just one human being who wrote them all!) and when completing transactions often met so that the original deeds could be collected and checked against the copies that had been supplied earlier. The solicitor (or articled clerk) to whom one was rude over the telephone when under great pressure suddenly became one's best friend and the lawyers shared tea and biscuits, face to face - no charging on time as scale fees operated. Land registration changed much of that personal contact, with completions almost invariably taking place through the post (or other means of delivery), and over a period of time those wonderful old manuscripts will probably have greater value than when they were a vital part of the title - perhaps even more than the property itself. Failing which, as some know, they make 'wonderful' lampshades.

Enough sentimentality and back to the real world. Why should one get excited by the new Act? Why should the readers of this journal be interested? It is the lawyer's problem and that is why they are paid. In any event, if election to high office were dependent upon the sympathy vote, one suspects that solicitors would lose their deposit and be placed alongside the UK entry in the Eurovision Song Contest this year, at the bottom of the pile with nil points.

Lawyers, however, like to share their worries and anxieties with their clients, and of the many changes the following might be of most relevance or interest to readers.

\section{REGISTRATION OF LEASES}

A lease of more than seven years from the date of the grant (even with a break clause) or assigned with more than seven years unexpired has to be registered, as do leases taking effect more than three months ahead even if granted for seven years or less. Under the previous regime, only leases of more than 21 years required registration. The intention is that all leases over three years in due course will have to be registered. This power is reserved to the Registrar under s. 118 of the Act. 
One disadvantage for the leaseholder is that there will be a registration fee, and another is that to achieve registration stamp duty has to be paid and therefore what is in effect currently a voluntary tax on non-registerable leases will catch many more. This is in fact only a temporary distinction, because from 1 December 2003 stamp duty land tax will come into force and, being payable on transactions, will cease to be a voluntary charge and will be payable whether the document is registerable or not.

It is perhaps timely to remind readers that the legal interest in land does not pass until the registration has taken place (s. 27(i)), and this should be borne in mind in particular when the need arises to determine who the tenant or the landlord is at any time for the service of notices. Clearly, the more interests that are registerable the greater the need to have this in mind.

\section{OPEN REGISTER FOR LEASES AND MORTGAGES}

Apart from the substantial increase in the number of registered interests in property by reason of shorter leases having to be recorded, a very significant and a momentous change is that, for the first time, it is possible by virtue of s. 66 of the Act for anyone to obtain, inter alia, a copy of a newly registered lease and charge on or after 13 October or any document not referred to in the register but in the custody of the Registrar. Previously the production of such copies was at the Registrar's discretion (eg for criminal investigation).

The original s. 112 of the 1925 Land Registration Act stated that apart from certain specific exceptions the registers of title could only be inspected by the registered proprietor or an authorised person. This was relaxed considerably by the Land Registration Act 1988 (which came into force on 3 December 1990), but leases and charges were specifically excluded.

The opening up of leases and mortgages to inspection is therefore a continuation of the openness that is being encouraged in relation to the ownership of land (although balancing this with other legislation including the Human Rights Act 1988, particularly Article 8 of the Convention - the right to respect for private and family life - the Data Protection Act 1988 and the Freedom of Information Act 2000 is worthy of a $\mathrm{PhD}$ in itself). Historically, and until 13 October, landlords and tenants could be comforted by the knowledge that the lease terms were private (other than in exceptional circumstances). Indeed, as a belt and braces, many agreements for leases contained and do contain provisions for confidentiality (as an aside one wonders why clauses in agreements which state that the contents of the document are to be confidential do not say that the contents, apart from the confidentiality clause, are to remain secret, otherwise one is not able to reply in the affirmative to a query whether the agreement is confidential, because that would be a breach!).

The new rules do, however, provide some degree of protection so 


\section{Editing}

Tests

\section{Procedures}

\section{Portfolios}

that application can be made under Rule 136 to the Registrar to designate a relevant document (commonly likely to be a lease) as an exempt information document if the applicant claims that the document contains prejudicial information; provided that the Registrar is satisfied that the applicant's claim is not groundless, he will be obliged so to designate the relevant document. It should be noted that as the tenant will be the party applying for registration of the lease, if the landlord is concerned about the public obtaining full details of the document there should be an obligation in the agreement for the lease for the application by the tenant to specify that it should be an exempt information document at the request of the landlord and the form of lease with the required extracts removed should be attached.

Prejudicial information is defined under Rule 131 as information that relates to the person applying for the exemption such that if disclosed to the other person (whether to the public generally or specific persons) it would or would be likely to cause substantial unwarranted damage or substantial unwarranted distress to the applicant or another'.

The Rules do enable anyone to apply for an official copy of an exempt information document, and the Registrar is obliged to give notice of an application to the person who made the application for it to be an exempt information document unless he is satisfied that such notice is unnecessary or impracticable. If the Registrar decides that none of the information excluded from the edited information document is prejudicial information, or although all or some of the information excluded is prejudicial information, the public interest in providing an official copy of the exempt information document to the applicant outweighs the public interest in not doing so, then he must provide an official copy of the exempt information document to the applicant.

It is not hard to imagine that many human hours will be spent in deciding what to exclude from the document before applying for registration, and will the Land Registry have the time or inclination to investigate whether the claim is groundless, whatever that may mean? What about the time expended in considering an application for an official copy of an exempt information document? The mind boggles.

At least, one may think, no one will be able to get hold of copies of an existing portfolio of registered leases. Sorry, but people only have two years, from 13 October, to go through their whole portfolio and decide whether any of the leases (or other so far unavailable documents) contain what is considered to be prejudicial information; one can then apply for those to be exempt information documents in that two-year transitional period. This may not seem like very long for busy people who have a job to do and a portfolio of 1,000 registered leasehold interests. Well, they should think themselves lucky: in the original draft rules the transitional period was only planned to be one year. 


\section{Design}

\section{Squatters}

Requirements
As can be imagined, a variety of concerns were expressed in the responses to the Land Registry consultation paper on the Rules in this area. Although this paper has concentrated so far on leases, the availability of copies of mortgages as well might, for example, be useful to enable someone to find out how much a potential litigation target owes to his lender.

Clients might now wish to employ designers to work alongside their solicitors so that it can be made more difficult for an inquisitor to work out what has been excluded. Perhaps it would now be better to put the break clause in the middle of the service charge schedule to put the applicant off the scent. It may be the rent-free period will come in the middle of the insurance covenant. Perhaps certain provisions will be retained in the agreement for lease and not registered provided that the relevant party is happy (unlikely) to rely upon the privity of contract arrangement and accept that the clause will not necessarily run with the land and be binding on successors in title. Life will not be as one knew it.

\section{ADVERSE POSSESSION}

Another major change relates to adverse possession, governed by Schedule 6 of the Act. The registered proprietor can be replaced on the register by a squatter in appropriate circumstances. A squatter will be able to apply for registration if adverse possession has been enjoyed for at least ten years, although the estate need not have been registered throughout the period. Application can also be made to be registered as a proprietor of a registered estate if:

- in the period of six months ending on the date of the application, the applicant ceased to be in adverse possession because of eviction by the registered proprietor or someone claiming under him

- on the day before his eviction he was entitled to make an application because he had been in adverse possession for the period of ten years

- the eviction was not pursuant to a judgment for possession.

There is an exception to this alternative application, and that is that the application cannot be made if the person is a defendant in proceedings which involve asserting a right to possession of the land, or a judgment for possession of the land has been given against him in the last two years.

Rule 188 requires the application to be made in Form ADV1 and accompanied by a statutory declaration made not more than one month before the application is taken to have been made, together with any supporting statutory declarations to provide evidence of adverse possession. There are certain requirements as to the contents of the declaration, including the exhibiting of a plan enabling the extent of the land to be identified on the Ordnance 


\section{Conditions}

\section{Second attempt}

Survey map unless the application is to be registered as the proprietor of a registered rent charge.

The Registrar will be obliged to give notice of an application to interested parties, including the proprietor of the estate or any registered charge and any superior interest to a leasehold estate, and the Rules state that the person given notice has 65 business days to respond requiring the application to be dealt with under paragraph 5 of Schedule 6 to the Act, which contains conditions before the applicant can be registered. The first condition is that:

- it would be unconscionable because of any equity by estoppel for the registered proprietor to seek to dispossess the applicant, and

- the circumstances are such that the applicant ought to be registered as the proprietor.

The second condition is that the applicant is for some other reason entitled to be registered as the proprietor of the estate. The third condition is that:

- the land to which the application relates is adjacent to the land belonging to the applicant

- the exact line of the boundary between the two has not been determined under the Rules under s. 60 of the Act

- for at least ten years of the period of adverse possession ending on the date of the application the applicant (or any predecessor in title) reasonably believed that the land to which the application relates belonged to him (where the application is made in the circumstances arising by reason of adverse possession ceasing because of eviction by the registered proprietor, the reference will be to the day before the date of the applicant's eviction)

- the estate to which the application relates was registered more than one year prior to the date of the application.

If an application is rejected, a further application can be made to be registered as a proprietor if the applicant is in adverse possession of the estate from the date of the application until the last day of the period of two years beginning with the date of its rejection. There are a few exceptions to this. It would, however, be sensible for the registered proprietor to act in this period to evict the squatter or try and come to a settlement.

It should be noted that generally where a person is registered under the Schedule to the Act as a proprietor of an estate it is vested in him free of any registered charge affecting the estate immediately before the registration. This will not apply where registration is in pursuance of an application determined by reference to whether any of the conditions in paragraph 5 of Schedule 6 apply. 


\section{BOUNDARIES}

Section 60 of the Act preserves the general boundaries rule, which does not determine the extent of the boundary, but in the absence of any contrary information various legal presumptions can be applied, for example, other than in the case of a public highway the boundary of a road extends to the middle. But Rule 118 now enables the proprietor of a registered estate to apply for the exact line of the boundary to be determined. There is a prescribed form (DB) and the application must be accompanied by a plan or a plan and a verbal description together with evidence to establish the exact line. The Registrar will need to have the identity and address of each owner who may be affected and must give them notice, unless of course the application is accompanied by an agreement in writing as to the exact line. The recipient of the notice has 20 working days to object, and there is scope for an extension.

If there is no objection, the Registrar must complete the application making an entry in the individual register together with other superior or inferior registered titles stating that the exact line is determined under s. 60 of the Act. Particulars, if appropriate, can also be added to the plan. In the case of a transfer of part or the grant of a lease of part, if there is a common boundary and there is sufficient information in the disposition to enable the Registrar to determine the exact line of the boundary, he may determine the exact line and, if he does, he must make an entry in the registers and on the plan.

\section{THE CROWN}

The Act permits the Crown to grant itself a fee simple which can then be registered. This is voluntary, and before the Act the Crown has been unable to register its landholdings (s. 79(1) of the Act).

\section{LAND AND CHARGE CERTIFICATES}

Surprisingly, perhaps, in view of the fact that land certificates and charge certificates are abolished, there is only one small reference in the Act and that is contained in paragraph 4 of Part 1 of Schedule 10. This says that rules may make provision about:

— when a certificate of registration of title to a legal estate may be issued

- the form and content of such a certificate

- when such certificate must be produced or surrendered to the Registrar.

The Rules, following responses to the consultation paper, now state 'It has been decided that no rule is necessary because the one proposed does not constitute a certificate of registration of title.' It will be issued for information only and will never have to be produced or surrendered to the Registrar. It will be issued under the Registrar's general power to provide a registered proprietor with information about or confirmation of the completion of an 
Forms

Closure application, and this will be done as a matter of practice whenever there is a change of proprietorship. The certificate will contain:

- the title number

- a verbal description of the land comprised in the registered estate

- the class of title and whether it is freehold or leasehold

- where the title is leasehold, short particulars of the lease

- the name and address of the proprietor of the registered estate

- guidance about how an official copy of the register of title and other information about it may be obtained.

A certificate can then be passed on to the client and will provide the buyer with confirmation he has been registered as owner, a record of the title details and guidance as to how to obtain more information about the individual register if required. This is quite a change and, for those who feel comforted by having some form of deed, therapy may be necessary.

\section{TRANSITION PERIOD FOR PRESCRIBED FORMS}

A transitional order contains a provision allowing the use of 'old' forms for a transitional period of three months or wherever the terms of a contract entered into before the Act came into force expressly requires their use.

\section{ADJUDICATOR}

The Lord Chancellor by s. 107 is required to appoint a person to be the adjudicator to the Land Registry, being someone who has a ten-year general qualification. The adjudicator's functions are to determine matters relating to an objection to an application to the Registrar and appeals with respect to entry into or termination of a network access agreement, which allows people requiring to have access to the Land Registry and not a member of it to carry out electronic conveyancing. The adjudicator can also deal with matters relating to the rectification or setting aside of a document. The lucky first office holder is Edward Cousins.

\section{TERMINATION OF REGISTERED ESTATES}

Rule 79(1) specifies that an application to record in the register the determination of a registered estate must be accompanied by evidence to satisfy the Registrar that the estate has been determined, and if he is so satisfied the registered title must be closed, and any notice on any other registered title must be cancelled. This will be particularly important in view of the number of shorter leases that will be registered. There are no specific formalities, and indeed the original and counterpart lease do not have to be lodged nor (currently) the land or charge certificates. But the most important requirement is that there is a statement certifying that the Landlord and Tenant Act 1954 does not apply, plus any other evidence that may be important. This will be 
increasingly important with the increasing number of shorter registered leases - good housekeeping will be required.

\section{NOTICES AND ADDRESSES FOR SERVICE}

The address for the owner of the interest in land or any charge is frequently not given the importance it deserves and is rarely changed. But the consequences of having an incorrect or outdated address could be serious. There are many circumstances when the Land Registry will, under the Rules, give notice to the proprietor - for example, in a claim for adverse possession as discussed earlier - and failure to respond might result in title being lost.

Rule 198(3) requires the Registrar to be given an address for service which is a postal address, whether or not in the UK, and one or two additional addresses for service may be given - postal, a document exchange or electronic, being an e-mail or other electronic address specified by direction from the Registrar. A fax address can also be given if the recipient has notified the Registrar in writing that he is willing to accept notice served by fax and giving the fax number. Rule 199(4) gives the time of service for the various methods, for example, the second working day after posting for an address in the UK, and the seventh for one outside the UK.

As can be appreciated from the above, it is really important that the notice arrives where it will be seen and acted upon in a timely fashion.

\section{CONCLUSION}

The Act and Rules are exceedingly comprehensive and this paper has only sought to summarise a small but important part. There are also significant changes to matters such as the methods of protecting third-party interests, what needs to be sent to the Land Registry when land is first registered and in reducing the scope and number of overriding interests, which are interests to which registered title is subject even though they are not mentioned on the registers, such as a public right and leases of land that do not have to be registered.

The adjustment to the changes will be a major one for property practitioners but will the professions and clients take full advantage of the opportunities and protections, in particular when editing leases and mortgages, and will the Land Registry really be able to cope? At the end of the day, time and money may well mean that enthusiasm may be tempered by reality so far as the client is concerned. Is it a price worth paying?

It has been said that many property solicitors faced with the changes brought about by the 1925 Land Registration Act (and the very significant changes brought about by the Law of Property Act of that year) left the profession. Hopefully today's lawyers are made of sterner stuff.

\section{(C) Geoffrey Silman}

